\title{
Attitudes About Wife Beating: A Comparison of Medical Students and Arts Students
}

\author{
MARNIE A. McCALL, M.D., C.C.F.P., and GAIL C. WEBBER, M.D.
}

\begin{abstract}
An inventory of beliefs about wife beating was used to compare the attitudes of medical students and arts students to woman abuse. Data were collected from 66 first year medical students, 56 third year medical students, and 66 arts students. All groups showed similar relatively sympathetic attitudes overall toward battered women, and there was no significant difference in the three groups. Age, education, marital status, and personal or close experience with abuse did not affect attitudes. Female respondents were shown to be statistically more sympathetic to battered women than men in two of the three subscales, but the scores were so close that this may not translate into a clinically significant finding.
\end{abstract}

\section{INTRODUCTION}

W OMAN ABUSE IS AN IMPORTANT HEALTH CARE ISSUE that affects women of all backgrounds in every country in the world. All women, due to their gender alone, are at risk to be victims of violence. Violent acts against women can take many forms, including physical battering, murder, sexual assault, and child abuse. The individual who commits one kind of violence against a woman is likely to commit other forms of violence against her, her children, and other women. ${ }^{1}$ In the United States, four million women are physically abused by their male partners each year. ${ }^{2}$ In Canada, at least 1 in every 10 Canadian women living with a man will be battered at some time during their relationship. ${ }^{3}$ More women are maimed or murdered by their partners or expartners in a year than are injured or killed in car accidents. ${ }^{4}$ Surveys have revealed that
$51 \%-70 \%$ of battered women with children reported that the batterer abused the children as well. .,

Physicians can play a crucial role in the identification of battered women and the coordination of an appropriate intervention plan for them. Victims of violence are more likely to turn to their physicians for help than to psychiatrists, police officers, or lawyers. ${ }^{7}$ It has been stated that $80 \%$ of abused women report their injuries to medical personnel at least once and $40 \%$ seek medical attention on at least five different occasions. ${ }^{8}$

Unfortunately, physicians are often ill-prepared to recognize and appropriately treat victims of violence. Several studies have demonstrated underidentification of battered women in emergency room settings. ${ }^{9-11}$ Physicians in community practices also underrecognize and underdocument woman abuse. A recent survey of Ontario family physicians in one rural

Queen's University, Kingston, Ontario, Canada. 
and two urban communities revealed that $70 \%$ of physicians felt they identified less than half of the abused women in their practices. ${ }^{12}$ Lack of physician initiative was cited by the participating physicians as one of the three most common reasons for failing to detect abused women. In another Canadian study, 29 family physicians were personally interviewed regarding their perceptions of wife battering. ${ }^{13}$ Thirty-eight percent indicated that they never asked their patients directly about the possibility of violence, and $45 \%$ indicated that no cases of wife battering had occurred within their practices over the past 12 months.

A study in a Midwestern community of all adult women seeking health care from a family practice clinic over a 2-month period revealed that 85 of 374 women admitted to physical assault by their partners within the past year, an incidence rate of $22.7 \%$. Only $2 \%$ of all respondents were asked about verbal abuse by their physicians at their most recent office visit, and only $1.7 \%$ were asked about physical abuse. ${ }^{14}$ Asking the patient directly about the possibility of violence is the most effective method for the assessment of abuse, according to Anne Flitcraft, a well-known researcher in the area. ${ }^{2}$

The detection of woman abuse requires a high index of suspicion and a nonjudgmental and nonthreatening response. ${ }^{15}$ However, interviews with physicians in the past have revealed that half do not view the diagnosis and management of spousal assault as real medicine. ${ }^{16}$ These attitudes could be due to a number of factors, including inadequate medical school training about domestic violence, conservative beliefs about the family, or the timeconsuming treatment involved. ${ }^{17}$ In addition, the professionalization process, which occurs in medical school and which has been shown to cause a decrease in the expression of humanistic attitudes, ${ }^{18}$ may have significant adverse effects on attitudes about wife abuse.

Having recognized that the medical response to woman abuse is inadequate, the purpose of the present study was to examine the attitudes of a group of medical students as they entered medical school, compare their attitudes with medical students nearing the completion of their undergraduate education, and use a group of university students in a nonprofessional faculty as a control. The study was designed to determine if medical students entered medical school with sympathetic or nonsympathetic attitudes, if they had similar attitudes to other students on entry, and if their attitudes changed as they progressed in their education.

\section{MATERIALS AND METHODS}

A questionnaire was administered to students at Queen's University, Kingston, Ontario, between November 1992 and January 1993. Sixty-six first year medical students (M1) and 56 third year medical students (M3) participated. This represented $88 \%$ and $75 \%$ of each class, respectively. The first year medical students were surveyed during their first semester of medical school. The questionnaires were administered during whole class lectures with a short personal introduction by one of the authors. Participation was voluntary, and no identifying information was requested on the questionnaire. Third year arts students (A3) enrolled in a geography course were chosen as a control for the first year medicine group. It was assumed that they would be similar in terms of number of years of postsecondary school education and social background. The questionnaire was completed by 94 geography students. Responses from all male students were used (24), and a sample of responses from the 70 remaining female students were randomly chosen to approximate the sex distribution of the first year medical class. Because the number of students present in each class on the days the questionnaire was distributed was not determined, the exact response rate for the two medical classes and the geography class is unknown.

The questionnaire consisted of two parts (see Appendix). The first part asked for basic demographic information about the respondent, and the second part consisted of three subscales of the Inventory of Beliefs About Wife Beating (IBWB). ${ }^{19}$ The demographic information requested included age, gender, marital status, and years of postsecondary school education. Respondents also were 
asked to indicate if they had had any personal experience with woman abuse as either victim or abuser or any close experience with abuse in that a friend or family member had been involved.

The IBWB defines wife beating as "hitting intended to inflict pain." The three subscales used were the 12-item "Wife Beating is Justified" scale, the 5-item "Help Should be Given" scale, and the 4-item "Offender Is Responsible" scale. Statements are on a 7-point Likert scale from "strongly agree" (7) to "strongly disagree" (1). The most sympathetic scores toward battered women are 35 for the Help (HG) subscale and 28 for the Offender (OR) subscale. The value of the individual items for the Justify (WJ) subscale is reversed, with "strongly agree" worth 1 and "strongly disagree" worth 7, and therefore 12 is the most sympathetic score for this subscale.

The Kruskal-Wallis one-way analysis of variance was used to compare the three groups of students for differences in their beliefs about wife beating.

\section{RESULTS}

The sex distribution of the three groups is illustrated in Table 1. The sex distribution of the M3 group was significantly different from the other two groups $\left(\chi^{2}=8.79, \mathrm{df}=2\right.$, $p=0.01)$. There was no significant difference in marital status between the three groups, with 173 of 184 students being single, 3 engaged, 8 married, and 4 not replying. The mean age of the A3 group was 21.7 years, significantly younger than the other two groups (mean age of M1 was 23.6 years, and mean age of M3 was 24 years) $(p<0.05)$. There was also a significant difference in years of postsecondary school education among the

TAble 1. Sex Distribution of Three Groups

\begin{tabular}{|c|c|c|c|}
\hline \multirow[b]{2}{*}{ Group } & \multicolumn{2}{|c|}{ Sex } & \multirow[b]{2}{*}{ Total } \\
\hline & $F$ & $M$ & \\
\hline A3 & $43(65 \%)$ & $23(35 \%)$ & 66 \\
\hline M1 & $39(59 \%)$ & $27(41 \%)$ & 66 \\
\hline M3 & $22(39 \%)$ & $34(61 \%)$ & 56 \\
\hline Total & 104 & 84 & 188 \\
\hline
\end{tabular}

three groups, with the mean for the A3 group being 3.59 years vs a mean of 4.92 years for M1 and 5.96 years for M3 $(p<0.01)$.

Table 2 illustrates that there were very few students who reported personal experience with abuse as the victim or abuser. Much higher numbers of students had close experiences with abuse. Twenty-five A3 students (38\%), $36 \mathrm{M} 1$ students (54\%), and $16 \mathrm{M} 3$ students $(29 \%)$ reported positively when asked if a friend or family member had had a personal experience with abuse. The questionnaire response scores obtained from this "close experience" group of 77 students were compared with the scores of the rest of the student population $(n=107)$ to determine if proximity to abuse affected attitudes. The difference in scores on each of the three subscales between the two populations was not statistically significant.

There was no significant difference in scores between the three groups for the three IBWB subscales (Table 3). Age, education, marital status, and personal experience with abuse did not affect attitudes. There was a significant gender difference in attitudes in the "Help Should be Given" and "Wife Beating is Justified" subscales (Table 4), with women being more supportive of battered wives than men.

\section{DISCUSSION}

Research over the past few years has indicated that physicians' responses to battered women may be less than satisfactory. In this study of arts and medical students' attitudes toward battered women, all groups displayed attitudes that were similar and relatively sympathetic. The fact that medical students begin their training with these supportive attitudes

Table 2. Personal Experience with Abuse as Abuser (A), VICTIM (V), OR UNDOCUMENTED (U) ${ }^{\mathrm{a}}$

\begin{tabular}{lcccr}
\hline Group & $A$ & $V$ & $U$ & Total \\
\hline A3 & 1 & 4 & 0 & 5 \\
M1 & 0 & 2 & 0 & 2 \\
M3 Total & 0 & 1 & 2 & 3 \\
$\quad 1$ & 7 & 2 & 10 \\
\hline
\end{tabular}

${ }^{a}$ Respondent did not specify if personal experience was as abuser or victim. 
TABle 3. IBWB Subscale SCORES by Group

\begin{tabular}{lccc}
\hline Subscale & Mean & Median & $p$ \\
\hline A3 & 22.44 & 23.00 & \\
M1 & 22.18 & 23.00 & 0.15 \\
M3 & 21.68 & 23.00 & \\
Wife beating is Justified & & & \\
A3 & 14.43 & 12.00 & 0.29 \\
M1 & 14.39 & 12.00 & \\
M3 & 15.65 & 12.00 & \\
Offender is Responsible & & & 0.72 \\
A3 & 20.97 & 21.50 & \\
M1 & 21.15 & 22.00 & \\
M3 & 20.52 & 21.50 & \\
\hline
\end{tabular}

and maintain them at least partway through their training is encouraging. If current attitudes are carried over into practice, future physicians may be better at detecting and managing wife abuse than physicians currently in practice are considered to be.

The study does raise several questions. One cannot assume that sympathetic attitudes toward battered women as measured by the IBWB will translate into good management of the problem in the emergency department or family physician's office. Perhaps the IBWB does not measure the attitudes that actually determine behavior, especially in a busy, at times hectic medical setting. Beliefs about the efficacy of medical intervention in lowering the incidence of wife abuse may be greater determinants of behavior than the attitudes that have been measured by the IBWB. It is also possible that training about wife abuse in medical school and the recognition of the timeconsuming treatment required are greater determinants of behavior than attitudes.

Political correctness may have affected responses to the questionnaire. Although social desirability response bias was measured during the construction and validation of the IBWB and did not appear to be a major contaminant of the scale, one student commented that he felt it was unlikely that respondents with unsympathetic attitudes would write them in front of peers.

Several respondents also had suggestions for dealing with husbands who batter their wives beyond the options in the questionnaire, even though comments were not solicited. For example, one of the items in the "Offender Is Responsible" subscale states "The best way to deal with wife beating is to arrest the husband." Nine respondents commented on this item, primarily to indicate that arrest would not solve the problem, and therapy or counseling also is needed. ltems such as this may have induced a uniform answer because the option they present could be considered as extreme.

Even though the numbers are small, it is interesting to note that more than twice as many arts students had personal experience with abuse as victims than did medical students in both classes combined. However, a

TABLE 4. IBWB SubSCAle SCORES by SEX

\begin{tabular}{llll}
\hline Subscale & Mean & Median & $p$ \\
\hline Help Should be Given & & & \\
$\quad$ Female & 22.61 & 23.00 & $<0.05$ \\
$\quad$ Male & 21.53 & 22.00 & \\
Wife Beating is Justified & 13.90 & 12.00 & $<0.05$ \\
$\quad$ Female & 15.80 & 13.00 & \\
$\quad$ Male & 20.98 & 22.00 & $>0.05$ \\
Offender is Responsible & 20.81 & 22.00 & \\
$\quad$ Female &
\end{tabular}


history of personal experience with abuse did not affect responses to the IBWB. In fact, the one respondent in the $\mathrm{A} 3$ group who admitted to being an abuser had sympathetic scores on the IBWB. This warrants further examination. Similarly, the larger number of students (77) who had had close experience with abuse had IBWB responses that did not differ significantly from those of the students who had not had close experience with the problem. Learned behavior or cultural attitude would seem to outweigh emotional response in determining attitudes to this form of abuse.

This study did identify a gender difference in attitudes. There is a trend for women to be less likely to believe that wife beating is justified and more likely to believe that help should be given to the victim. However, the differences were so small that it is unlikely they would translate into diagnostic or therapeutic differences in practice.

It has been suggested that battered women deserve better care by the medical profession than they have received thus far. Medical students in this study appear to have generally sympathetic attitudes to abused women. With increased knowledge and societal focus on this problem, the current generation of students may provide a better response to it than their predecessors did. It is, however, a responsibility of medical educators to ensure this by devising a curriculum that effectively places this important problem in the forefront of medical undergraduate education.

\section{ACKNOWLEDGMENTS}

Thanks to Dr. Ron Lees for his advice on this project and Drs. David and Rita Kawatu for their assistance with statistical analysis. This research was funded by the Advisory Research Committee of Queen's University.

\section{REFERENCES}

1. Candib L. Violence against women as a gender issue. In: Violence education: Toward a solution. Kansas City, MO: Society of Teachers of Family Medicine, 1992.
2. Flitcraft A. Battered women in your practice? Patient Care 1990;24:107.

3. MacLeod L. Wife battering in Canada: A vicious circle. Ottawa: Canadian Advisory Council on the Status of Women, 1980.

4. McGoldrick K. Wife-beating: Everyday mayhem and murder (Editorial). JAMWA 1986;41:35.

5. Walker LEA, Browne A. Gender and victimization by intimates. J Pers 1985;53:179.

6. Bowker LH, Arbitell M, McFerron JR. On the relationship between wife beating and child abuse. In: Yllo K, Bograd M, eds. Feminist perspectives on wife abuse. Newbury Park, CA: Sage, 1988.

7. Mehta P, Dandrea LA. The battered woman. Am Fam Phys 1988;37:193.

8. Morrison L. The battering syndrome. A poor record of detection in the emergency department. J Emerg Med 1988;6:521.

9. Stark E, Flitcraft A, Frazier W. Medicine and patriarchal violence: The social construction of a "private event." Int J Health Serv 1979;9:461.

10. McLeer SV, Anwar RAH. A study of battered women presenting in an emergency department. Am J Public Health 1989;79:65.

11. Rounsaville B, Weissman MM. Battered women: A medical problem requiring detection. Int Psychiatry Med 1977-78;8:191.

12. Ferris LE, Tudiver F. Family physicians' approach to wife abuse: A study of Ontario, Canada, practices. Fam Med 1992;24:276.

13. Nuttall Se, Greaves LJ, Lent B. Wife battering: An emerging problem in public health. Can J Public Health 1985;76:297.

14. Hamberger KL, Saunder DG, Hovey M. Prevalence of domestic violence in community practice and rate of physician inquiry. Fam Med 1992;24:283.

15. Ontario Medical Association Committee on Wife Assault. Reports on wife assault. Can Med Assoc J 1991;144(suppl).

16. Borkowski M, Murch M, Walker V, eds. Marital violence, the community response. London: Tavistock, 1983.

17. Rose K, Saunders DG. Nurses' and physicians' attitudes about abuse: The effects of gender and professional role. Health Care Women Int 1986;7:427.

18. Rosenburg DA, Silver HK. Medical students' abuse: An unnecessary and preventable cause of stress. JAMA 1984;251:739.

19. Saunders DG, Lynch AE, Grayson M, Linz C. The inventory of beliefs about wife-beating: The construction and initial validation of a measure of beliefs and attitudes. Violence Victims 1987;2:39.

Address reprint requests to: Marnie A. McCall, M.D., C.C.F.P. Department of Family Medicine Queen's University 220 Bagot St., P.O. Bag 8888 Kingston, ON Canada K7L 5E9 


\section{APPENDIX \\ ATTITUDES TOWARD WOMEN IN SOCIETY}

Please provide the following information about yourself. There will be no identifying information on this questionnaire.

Age Sex M F (circle)

Marital status

Years of postsecondary school education

Have you any personal experience with woman abuse (hitting of a women to inflict pain)? Yes __ No . If yes please check one of the following: self as victim self as abuser

Has anyone close to you (friend or family member) had a personal experience with woman abuse? Yes

No

Below are a number of statements about violence toward wives which some people agree with and others disagree with. PLEASE INDICATE HOW MUCH YOU AGREE OR DISAGREE WITH EACH STATEMENT BY MARKING THE APPROPRIATE BOX WITH AN "X". Please anwer all the questions.

"Beating" is used to mean repeated hitting intended to inflict pain.

1. A husband has no right to beat his wife even if she breaks agreements she has made with him.

2. Even when a wife's behavior challenges her husband's manhood, he's not justified in beating her.

3. A wife doesn't deserve a beating even if she keeps reminding her husband of his weak points.

4. Even when women lie to their husbands they do not deserve to get a beating.

5. A sexually unfaithful wife deserves to be beaten.

6. Sometimes it is OK for a man to beat his wife.

7. It would do some wives some good to be beaten by their husbands.

8. Occasional violence by a husband toward his wife can help maintain the marriage.

9. There is no excuse for a man beating his wife.

10. A woman who constantly refuses to have sex with her husband is asking to be beaten.

\begin{tabular}{|c|c|c|c|c|c|c|}
\hline $\begin{array}{c}\text { Strongly } \\
\text { Agree }\end{array}$ & Agree & $\begin{array}{c}\text { Slightly } \\
\text { Agree }\end{array}$ & $\begin{array}{l}\text { Neither } \\
\text { Arree nor } \\
\text { Disagree }\end{array}$ & $\begin{array}{l}\text { Slightly } \\
\text { Disagree }\end{array}$ & Disagree & $\begin{array}{l}\text { Strongly } \\
\text { Disagree }\end{array}$ \\
\hline & & & & & & \\
\hline & & & & & & \\
\hline & & & & & & \\
\hline & & & & & & \\
\hline & & & & & & \\
\hline & & & & & & \\
\hline & & & & & & \\
\hline & & & & & & \\
\hline & & & & & & \\
\hline & & & & & & \\
\hline & & & & & & \\
\hline & & & & & & \\
\hline & & & & & & \\
\hline & & & & & & \\
\hline & & & & & & \\
\hline & & & & & & \\
\hline & & & & & & \\
\hline
\end{tabular}




\begin{tabular}{|c|c|c|c|c|c|c|c|}
\hline & $\begin{array}{c}\text { Strongly } \\
\text { Agree }\end{array}$ & Agree & $\begin{array}{c}\text { Slightly } \\
\text { Agree }\end{array}$ & $\begin{array}{l}\text { Neither } \\
\text { A } \\
\text { Disea noree }\end{array}$ & $\begin{array}{c}\text { Slightly } \\
\text { Disagree }\end{array}$ & Disagree & $\begin{array}{l}\text { Strongly } \\
\text { Disagree }\end{array}$ \\
\hline \multicolumn{8}{|l|}{$\begin{array}{l}\text { 11. Episodes of a man beating his wife are the } \\
\text { wife's fault. }\end{array}$} \\
\hline \multicolumn{8}{|l|}{$\begin{array}{l}\text { 12. Wives could avoid being battered by } \\
\text { husbands if they knew when to stop } \\
\text { talking. }\end{array}$} \\
\hline \multicolumn{8}{|l|}{$\begin{array}{l}\text { 13. If I heard a woman being attacked by her } \\
\text { husband, it would be best that I do } \\
\text { nothing. }\end{array}$} \\
\hline \multicolumn{8}{|l|}{$\begin{array}{l}\text { 14. If I heard a woman being attacked by her } \\
\text { husband, I would call the police. }\end{array}$} \\
\hline \multicolumn{8}{|l|}{$\begin{array}{l}\text { 15. Wife beating should be given a high priority } \\
\text { as a social problem by government } \\
\text { agencies. }\end{array}$} \\
\hline \multicolumn{8}{|l|}{$\begin{array}{l}\text { 16. Social agencies should do more to help } \\
\text { battered women. }\end{array}$} \\
\hline \multicolumn{8}{|l|}{$\begin{array}{l}\text { 17. Women should be protected by law if their } \\
\text { husbands beat them. }\end{array}$} \\
\hline \multicolumn{8}{|l|}{$\begin{array}{l}\text { 18. Cases of wife beating are the fault of the } \\
\text { husband. }\end{array}$} \\
\hline \multicolumn{8}{|l|}{$\begin{array}{l}\text { 19. Husbands who batter should be responsible } \\
\text { for the abuse because they should have } \\
\text { foreseen that it would happen. }\end{array}$} \\
\hline $\begin{array}{l}\text { 20. The best way to deal with wife beating is to } \\
\text { arrest the husband. }\end{array}$ & & & & & & & \\
\hline $\begin{array}{l}\text { 21. Husbands who batter are responsible for } \\
\text { the abuse because they intended to do it. }\end{array}$ & & & & & & & \\
\hline
\end{tabular}

